\title{
Studies on Multiple Thyroid Cell Membrane-directed Antibodies in Graves' Disease
}

\author{
Margita Zakarija, Angela Garcia, and J. Maxwell McKenzie \\ Department of Medicine, University of Miami School of Medicine, Miami, Florida 33101
}

\begin{abstract}
Immunoglobulin $\mathbf{G}$ was obtained from the serum of a woman who had given birth to three children with a delayed onset of hyperthyroidism; the clinical events were due to the coexistence of thyroid-stimulating antibody (TSAb) and an inhibitor of TSAb in the maternal serum. The current studies explore the possible existence of additional thyroid membrane-directed antibodies. Human thyroid slices, cells in monolayer culture, and functioning

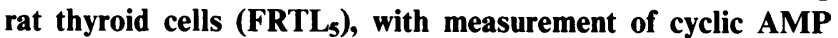
concentration, were used for TSAb assays. Assays of the inhibition of binding of ${ }^{125}$ I-thyrotropin (TSH) to its receptor used human thyroid and FRTL 5 cells, and human thyroid and guinea pig fat cell membranes as receptors. All activities were associated with IgG $\kappa$. Fractions of IgG $\kappa$ obtained by adsorption to and the desorption from human thyroid and guinea pig fat cell preparations and $F\left(a^{\prime}\right)_{2}$ and Fab fragments of the parent IgG were tested. Results indicated that there were three activities in the IgG, namely, TSAb; an inhibitor of TSH-binding that was active in all species and preparations tested, and was effective as Fab and $\mathbf{F}\left(\mathbf{a b}^{\prime}\right)_{2}$ on both particulate and solubilized thyroid membranes; and an enhancer of TSH-binding (e.g., $\cong 220 \%$ increase in binding) that was relatively specific for human thyroid membranes only in particulate form, was not adsorbed by fat, and was active as $\mathbf{F}\left(\mathbf{a b}^{\prime}\right)_{2}$, but minimally as Fab. The concept is developed that dilution of the total IgG, experimentally in vitro or by metabolic clearance in vivo in neonates, determines the effect on either thyroid stimulation or TSH-binding. The incidence of such multiple antibodies and their interaction remains to be determined.
\end{abstract}

\section{Introduction}

Thyroid-stimulating antibody (TSAb), ${ }^{1}$ by an action on the thyroid receptor for thyrotropin (TSH), causes hyperthyroidism in

Dr. Garcia's present address is Hospital de la Santa Creu i Sant Pau, Faculty of Medicine, Autonomous University of Barcelona, Barcelona, Spain. Dr. J. M. McKenzie is the Kathleen and Stanley Glaser Professor of Medicine.

Address all correspondence to Dr. Margita Zakarija, Department of Medicine (R-93), University of Miami School of Medicine, P.O. Box 016760, Miami, FL 33101. 1985

Received for publication 2 October 1984 and in revised form 22 July

1. Abbreviations used in this paper: DeL, TSAb-IgG from the serum of a patient with Grave's disease; FRTL ${ }_{5}$, functioning rat thyroid cell line; M's IgG, IgG purified from the serum of the mother of the family; NIH, National Institutes of Health; TBI, TSH-binding inhibition; TSAb, thyroid stimulating-antibody; TSH, thyrotropin.

J. Clin. Invest.

(C) The American Society for Clinical Investigation, Inc.

0021-9738/85/11/1885/07 \$1.00

Volume 76, November 1985, 1885-1891 the patient with Graves' disease (1) and neonatal hyperthyroidism in the offspring of a mother with a high level of the antibody in her blood (2). Measurement of antibodies to the TSH receptor is either by a thyroid-stimulation type of assay or by inhibition of the receptor-binding of ${ }^{125} \mathrm{I}$-TSH (3). The latter technique, TSH-binding inhibition (TBI), makes use of human thyroid membranes (4) or guinea pig fat cell membranes (5) as a source of TSH-receptor. We have recently conducted studies in a family wherein three children had a delayed onset of neonatal Graves' disease, explicable by the existence of a maternal IgG, in addition to TSAb, that temporarily inhibited the action of the TSAb (6).

In assessing the properties of the mother's IgG, we identified that at low concentrations it actually enhanced the binding of TSH to its receptor, but only when human thyroid membranes were used; with guinea pig fat cell membranes, the IgG showed only the capacity to inhibit binding of the ligand. We now report further analyses of this novel IgG, including indications for the existence of one or more additional thyroid membrane-directed antibodies in the same preparation.

\section{Methods}

TSAb and TBI assays with human thyroid slices and membranes. These have been described in detail $(1,7)$ and in brief are as follows. For TSAb, relatively normal human thyroid was obtained as the paranodular tissue removed during a lobectomy for a "cold" nodule. Slices of the tissue were incubated for $2 \mathrm{~h}$ with the test material and the assay response was an increase in cyclic AMP (cAMP), measured by radioimmunoassay (Becton Dickinson Immunodiagnostics, Orangebury, NY). In all TSAb assays where TSH was also used, it was National Institutes of Health (NIH)-TSH-B B $_{10}$, a gift from National Institute of Arthritis, Metabolism and Digestive Diseases, NIH. TBI assays, with either human thyroid or guinea pig fat cell membranes, used as radioligand ${ }^{125}$ I-labeled bovine TSH, highly purified and generously supplied by Dr. John Pierce of University of California at Los Angeles, to whom we express our thanks. The radioiodinated material was receptor purified (7) before use. Thytropar (Armour Pharmaceutical Co., Tarrytown, NY) was used for the assessment of nonspecific binding in all TBI assays. Control binding was the specific binding in the presence of $0.9 \% \mathrm{NaCl}-0.2 \%$ bovine serum albumin (BSA) instead of a test sample. The samples tested contained IgG usually below $1 \mathrm{mg} / \mathrm{ml}$ and normal IgG has no effect on TSH binding at such concentrations. For adsorption and desorption of the IgG, similar membrane fractions in much larger quantities, as indicated below, were prepared.

In order to test further the zoological specificity of the effects of IgG purified from the serum of the mother of the family (M's IgG), we carried out TSAb assays with porcine and simian thyroid slices, the latter provided from a baboon by Dr. T. Malinin of this Department of Surgery, and TBI assays with bovine and porcine thyroid cell membranes.

$T S A b$ and TBI assays with human thyroid and functioning rat thyroid cells $\left(F R T L_{5}\right)$ in culture. FRTL, cells were generously provided by Dr. L. D. Kohn of NIH; these cells, established by Ambesi-Impiombato and his colleagues (8), have been shown to respond to TSH and TSAb in terms of an increase in the concentration in cAMP (9). Using the cells in monolayer culture in 24-well plates we confirmed such responsiveness and then used them for testing M's IgG. They were also made the basis of a TBI assay and the details of both procedures are as follows.

Both assays were done in 24-well plates. Cells were grown in $6 \mathrm{H}$ 
medium (9) for $7 \mathrm{~d}$ and, after aspiration of the medium and thorough washing, for an additional 5-7 d period in 5H medium (9). For the TBI assay, cells that were originally plated at $10^{5}$ per well were washed with $20 \mathrm{mM}$ Tris, $50 \mathrm{mM} \mathrm{NaCl}, \mathrm{pH} \mathrm{7.4}$, and to each well $200 \mu \mathrm{l}$ of the following mixture was added: $100 \mu \mathrm{l} 20 \mathrm{mM}$ Tris, $0.5 \% \mathrm{BSA}, \mathrm{pH} 7.4$; $50 \mu$ l test sample in $0.9 \% \mathrm{NaCl}-0.2 \% \mathrm{BSA}$; (for total binding: $50 \mu \mathrm{l} 0.9 \%$ $\mathrm{NaCl}, 0.2 \% \mathrm{BSA}$; for nonspecific binding: $50 \mu \mathrm{l} 0.9 \% \mathrm{NaCl}, 0.2 \% \mathrm{BSA}$, containing $50 \mathrm{mU} \mathrm{TSH}) ; 50 \mu \mathrm{l}{ }^{125} \mathrm{I}-\mathrm{TSH}(\cong 10,000 \mathrm{cpm})$ in $20 \mathrm{mM}$ Tris, $0.5 \% \mathrm{BSA}, \mathrm{pH} 7.4$. Plates were placed in a $37^{\circ} \mathrm{C}$ air-incubator for $1 \mathrm{~h}$, after which time medium was aspirated and wells washed twice with 20 $\mathrm{mM}$ Tris, $50 \mathrm{mM} \mathrm{NaCl}, 0.2 \% \mathrm{BSA}, \mathrm{pH} 7.4$. To each well $0.3 \mathrm{ml} 1 \%$ Nonidet $\mathrm{P}-40$ was added and plates were left rocking gently for $1-2 \mathrm{~h}$ at room temperature. Solutions from each well were transferred by Pasteur pipettes to glass tubes,and radioactivity counted.

For the TSAb assay, cells that were originally plated at $5 \times 10^{4}$ per well were washed with PBS and $0.3 \mathrm{ml}$ of the following mixture added to each: $0.15 \mathrm{ml}$ Hanks' balanced salt solution (HBSS)-2 mM 3-isobutyl1 -methyl-xanthine- $0.4 \% \mathrm{BSA}+0.15 \mathrm{ml}$ test solution (or control) in HBSS. Incubation was for $2 \mathrm{~h}$ in an air-incubator at $37^{\circ} \mathrm{C}$ after which the solutions were aspirated. Addition of $0.3 \mathrm{ml}$ absolute ethanol was followed by leaving the plates, which were enclosed in Saran Wrap, at $-20^{\circ} \mathrm{C}$ for $16 \mathrm{~h}$. The ethanol solutions were then transferred to glass tubes and evaporated under $\mathrm{N}_{2}$. The residue was dissolved in $50 \mathrm{mM}$ sodium acetate buffer, $\mathrm{pH} 6.2$, for the radioimmunoassay of cAMP.

The procedure for human thyroid cells followed in detail that described by Dr. B. Rapoport et al. (10), to whom we are grateful for advice regarding the preparation of cells. The cells were obtained from one Graves' disease thyroid weighing $240 \mathrm{~g}$ and were used for TBI and TSAb assays as follows.

For the TBI assay, the procedure was identical to that with FRTL, cells, except that $10^{6}$ cells in medium 199 containing $10 \%$ fetal calf serum were seeded per well at $24 \mathrm{~h}$ before the assay. For the TSAb assay, $2.5 \times 10^{4}$ cells per well in a 96-well plate were used. After $24 \mathrm{~h}$ wells were washed with phosphate-buffered saline and the following mixture added to each: $100 \mu$ l hypotonic medium (11) containing $20 \mathrm{mM}$ Hepes, $2 \mathrm{mM}$ 3-isobutyl-1-methyl-xanthine, 0.3\% BSA, pH 7.4, $+100 \mu$ l test solution (or control) in hypotonic medium with BSA. BSA concentration was always adjusted to give with IgG a final protein concentration of $0.3 \%$. Incubation was for $4 \mathrm{~h}$ in an air-incubator at $37^{\circ} \mathrm{C}$ after which $100 \mu \mathrm{l}$ were taken from each well, diluted with $0.9 \mathrm{ml} 50 \mathrm{mM}$ sodium acetate buffer, $\mathrm{pH} 6.2$, and acetylated $(20 \mu \mathrm{l}$ triethylamine and $10 \mu \mathrm{l}$ acetic anhydride added per tube) before proceeding with the radioimmunoassay of cAMP in which the standards were also acetylated. All diluting and pipetting was done with automatic pipettes 25000 and 25004 (Micromedic Systems, Inc., Horsham, PA).

Preparation of $\mathrm{IgG}$ and adsorption-desorption procedures are summarized in Table $\mathrm{I}$, which details steps to which reference is made in this paragraph. IgG was precipitated by addition of $\left(\mathrm{NH}_{4}\right)_{2} \mathrm{SO}_{4}$ to serum to achieve $40 \%$ saturation of the salt and that crude fraction was purified by chromatography on diethylaminoethyl cellulose (12); the IgG was separated into IgG $\kappa$ and IgG $\lambda$ fractions by affinity chromatography using monospecific antisera to $\kappa$ and $\lambda$ light chains (12). The antisera were supplied by Tago, Inc., Burlingame, CA, and were made monospecific as described (12). Since all TSAb activity was confined to IgGK (data not shown), as were activities in the TBI assay (6), this fraction was used for some of the studies. Adsorption of IgG $x$ to crude membranes was carried out as follows (Table I): $\mathbf{3 4} \mathbf{~ m g ~ I g G ~} \kappa$ was incubated with either fat cell membranes (209 mg protein) or human thyroid membranes $(353 \mathrm{mg}$ ) in $20 \mathrm{mM}$ Tris- $\mathrm{HCl}, 50 \mathrm{mM} \mathrm{NaCl}, \mathrm{pH} 7.4$ (step 1). After $1 \mathrm{~h}$ at $37^{\circ} \mathrm{C}$ mixtures were centrifuged at $11,000 \mathrm{~g}$ for $20 \mathrm{~min}$ (step 2) and pellets resuspended in the same buffer (step 3). This procedure was repeated twice (steps 4-6). All corresponding supernatant solutions, representing IgG $\kappa$ not adsorbed to membranes, were pooled, concentrated, dialysed

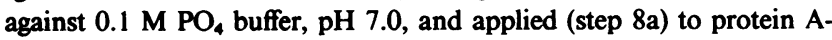
Sepharose 4B (Pharmacia Fine Chemicals, Uppsala, Sweden). Bound IgG $\kappa$ was eluted with $0.1 \mathrm{M}$ glycine- $\mathrm{HCl}, \mathrm{pH} 2.8$, neutralized, concentrated, and dialysed against $0.9 \% \mathrm{NaCl}$ solution (step $8 \mathrm{~b}$ ). $11,000 \mathrm{~g}$ pellets were resuspended in $0.1 \mathrm{M}$ glycine- $\mathrm{HCl}, \mathrm{pH} 2.8$ (step 7), incubated ro-
Table I. Membrane Purification of IgG

\begin{tabular}{|c|c|}
\hline Step & Procedure \\
\hline 1 & $\begin{array}{l}\text { Incubate IgG and membranes (from thyroid or fat cells) } \\
\times 1 \mathrm{~h} \text { at } 37^{\circ} \mathrm{C} \text { in Tris- } \mathrm{NaCl} \text {. }\end{array}$ \\
\hline 2 & Centrifuge $\times 11,000 \mathrm{~g} \times 20 \mathrm{~min}$. \\
\hline 3 & $\begin{array}{l}\text { Separate supernatant (save) and pellet; resuspend pellet } \\
\text { in Tris- } \mathrm{NaCl} \text {. }\end{array}$ \\
\hline 4 & Centrifuge suspension $\times 11,000 \mathrm{~g} \times 20 \mathrm{~min}$. \\
\hline 5 & $\begin{array}{l}\text { Separate supernatant (save) and pellet; resuspend pellet } \\
\text { in Tris- } \mathrm{NaCl} \text {. }\end{array}$ \\
\hline 6 & Centrifuge suspension $\times 11,000 \mathrm{~g} \times 20 \mathrm{~min}$. \\
\hline 7 & $\begin{array}{l}\text { Separate supernatant (save) and pellet; resuspend pellet } \\
\text { in glycine } \mathrm{HCl} \text {. }\end{array}$ \\
\hline 8 & $\begin{array}{l}\text { (a) Pool supernatant solutions from steps } 3,5 \text {, and } 7 \text {; } \\
\text { concentrate, dialyse, chromatograph on protein A- } \\
\text { Sepharose; and }(b) \text { elute IgG with glycine- } \mathrm{HCl} \text {; } \\
\text { neutralize, concentrate, and dialyse. }\end{array}$ \\
\hline 9 & Incubate suspension from step $7 \times 30 \mathrm{~min}$ at $4^{\circ} \mathrm{C}$. \\
\hline 10 & Centrifuge suspension $\times 20,000 \mathrm{~g} \times 30 \mathrm{~min}$. \\
\hline 11 & $\begin{array}{l}\text { Separate supernatant solution, neutralize, concentrate, } \\
\text { and dialyse. }\end{array}$ \\
\hline 12 & $\begin{array}{l}\text { Chromatograph on protein A-Sepharose and elute with } \\
\text { glycine- } \mathrm{HCl} \text {; neutralize, concentrate, and dialyse. }\end{array}$ \\
\hline
\end{tabular}

Solutions obtained in this procedure are referred to in the text as Sup. Thyroid or Sup. Fat, i.e., supernatant solutions of thyroid and fat, respectively (step 8), and Des. Thyroid or Des. Fat, i.e., IgG desorbed from thyroid and fat, respectively (steps 9-12).

tating for $30 \mathrm{~min}$ at $4^{\circ} \mathrm{C}$ (step 9), and centrifuged for $30 \mathrm{~min}$ at 20,000 $g$ (step 10). Supernatant solutions containing IgG $x$ desorbed from fat or thyroid membranes were neutralized, concentrated, dialysed against 0.1 $\mathrm{M} \mathrm{PO}_{4}$ buffer, $\mathrm{pH} 7.0$ (step 11), and applied to Protein A-Sepharose from which bound $\mathrm{IgG} \kappa$ was eluted with glycine buffer and processed as described above. The protein A-Sepharose step was included to separate IgG $\kappa$ from other proteins released from membranes. From fat, $308 \mu \mathrm{g}$ IgG $\kappa$ was recovered, and from thyroid membranes, $767 \mu \mathrm{g}$, representing $0.9 \%$ and $2.26 \%$ of the initial $\mathrm{IgG} \kappa$, respectively.

$\mathrm{F}\left(\mathrm{ab}^{\prime}\right)_{2}$ and Fab fragments of $\mathrm{M}$ 's IgG were prepared by standard procedures $(13,14)$ except that in both instances the final step of purification was by chromatography on protein A-Sepharose to remove any remaining unbroken $\mathrm{IgG}$ or $\mathrm{Fc}$ fragments. The fractions were pure as tested by Ouchterlony technique, at a concentration of $\cong 17 \mathrm{mg} / \mathrm{ml}$ for $\mathrm{F}\left(\mathrm{ab}^{\prime}\right)_{2}$ and $\cong 6 \mathrm{mg} / \mathrm{ml}$ for $\mathrm{Fab}$ with rabbit anti-human $\mathrm{IgG} / \mathrm{Fc}$ (Behringwerke AG, Marburg, Federal Republic of Germany).

In various experiments a control, normal human IgG preparation, obtained from a pool of serum from over 100 subjects, was tested concomitantly. In many, as indicated, a standard TSAb-IgG was run in parallel with M's IgG; this standard was from serum of a patient with Graves' disease (DeL) who also had had children with neonatal Graves' disease, but in these instances the syndrome was present at birth. We are grateful to Professor R. Hoffenberg of the Medical School of the University of Birmingham, England, and his patient, for supplies of this serum.

IgG preparations used in TSAb assays with human thyroid (10) or $\mathrm{FRTL}_{5}$ cells in culture (9) were dialysed against hypotonic medium (11) for the former and HBSS for the latter.

The protein content of membrane preparations was estimated by the method of Lowry et al. (15) using BSA as standard; the concentration of IgG in solution was calculated by UV spectrophotometry at $280 \mathrm{~nm}$, assuming $E_{10 \mathrm{~mm}}^{1 \%}=13.5$.

For some studies crude membranes were solubilized in Triton $\mathrm{N}$ 101 as described in detail earlier (7); protein in these preparations was measured by the method of Bradford (16) 


\section{Results}

The aims of these experiments were to evaluate the characteristics of M's IgG that underlie the enhancement of ${ }^{125} \mathrm{I}-\mathrm{TSH}$ binding to human thyroid membranes and the biphasic effect (low concentrations of IgG stimulating and high concentrations not stimulating cAMP accumulation) in the TSAb assay. The results are, therefore, presented as a series of TBI assay experiments followed by a series of TSAb data, although the different preparations of IgG under study were obtained in sufficient quantities for aliquots of single batches of material to be used in various TBI and TSAb experiments.

TBI assay. As noted earlier, our patient's IgG, at low concentrations, enhanced the specific binding of ${ }^{125} \mathrm{I}$-TSH to human thyroid membranes, to as much as $\mathbf{2 5 0 \%}$ of control, but showed no such effect with membranes from guinea pig fat cells (6); solubilization of these preparations resulted in solely inhibitory effects of M's IgG occurring with both species of membrane (17). If M's IgG contained anti-TSH antibody, increased ${ }^{125} \mathrm{I}$ TSH precipitation would have occurred in TBI assays using solubilized membrane preparations, where the last step is addition of polyethylene glycol-IgG mixture to effect precipitation. This did not occur (17). To determine whether this enhancing effect reflected an organ (i.e., thyroid) specificity, we carried out similar TBI analyses with thyroids of other species, namely, of calf, pig, and rat. Although it was much less than observed with human thyroid membranes (but confirmed in replicate assays), there was enhancement of binding of ${ }^{125} \mathrm{I}-\mathrm{TSH}$ to particulate membranes from bovine thyroid and from the gland of a 2-yr-old pig; there was no enhancement, and only the inhibitory effect was obtained, when thyroid membranes from a 2-mo-old pig were used (Fig. 1). For rat thyroid, FRTL 5 cells in monolayer culture were used. As shown in Table II, it was necessary to change from HBSS to $20 \mathrm{mM}$ Tris $\mathrm{HCl}, 50 \mathrm{mM} \mathrm{NaCl}, 0.5 \%$ BSA, pH 7.4, for this experiment in order to obtain a useful percentage of specific binding of ${ }^{125}$ I-TSH. With these conditions the data shown in Fig. 2 were obtained; the figure also shows the enhancing effect of M's IgG on ${ }^{125} \mathrm{I}-\mathrm{TSH}$ binding to human thyroid cells in culture and the expected inhibition of binding, to both human and FRTL s cells, by the control (DeL) TSAbIgG (lesser concentrations of DeL's IgG, down to $10 \mu \mathrm{g} / \mathrm{ml}$, had

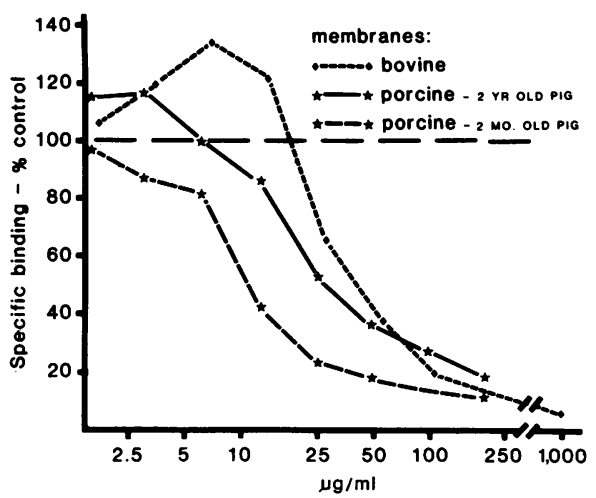

Figure 1. TBI assays with different membrane preparations. The abscissa shows the concentration of IgG that was the same for all assays. Each point is the mean of closely agreeing duplicates or triplicates in replicate assays. Membranes: bovine $=\mathbf{4 0} \mu \mathrm{g}$ protein, specific binding $16.9 \%$ (nonspecific $3.9 \%$ ); porcine $(2 \mathrm{yr})=25 \mu \mathrm{g}$ protein, specific binding $23.6 \%$ (nonspecific $6.3 \%$ ); porcine $(2 \mathrm{mo})=15 \mu \mathrm{g}$ protein, specific binding $22 \%$ (nonspecific $2.5 \%$ ).
Table II. ${ }^{125}$ I-TSH Binding to FRTL Cells in Culture

\begin{tabular}{llc}
\hline Incubation medium & Total binding & $\begin{array}{c}\text { Mean } \pm \text { SD } \\
(n=3)\end{array}$ \\
\hline & $\%$ & $c p m /$ well \\
125 I-TSH in HBSS, 0.5\% BSA, pH 7.4, & 6.1 & $622 \pm 33$ \\
$+50 \mathrm{mU}$ TSH & 1.0 & $85 \pm 7$ \\
& & \\
125 I-TSH in 20 mM Tris-HCl, 50 mM & 17.7 & $1678 \pm 37$ \\
NaCl, 0.5\% BSA, pH 7.4, & 1.0 & $87 \pm 8$ \\
$+50 \mathrm{mU}$ TSH & 1.3 & $118 \pm 13$ \\
No cells + ${ }^{125} \mathrm{I}-\mathrm{TSH}$ in Tris buffer & 1.1 & $98 \pm 8$ \\
$+50 \mathrm{mU}$ TSH & & \\
\hline
\end{tabular}

For details see Methods.

no effect on TSH binding). As shown, M's IgG was only inhibitory, and very potent as such, in influencing ${ }^{125} \mathrm{I}-\mathrm{TSH}$ binding to the rat cells.

The actions in some of these systems of the Fab and $F\left(a b^{\prime}\right)_{2}$ fragments of M's IgG and the standard (DeL's) TSAb-IgG were studied. As shown in Fig. 3, the enhancing effect of M's IgG on binding of ${ }^{125} \mathrm{I}$-TSH to particulate human thyroid membranes was retained fully by the $F\left(a b^{\prime}\right)_{2}$ fragment, but only to a minor extent by the Fab fragment; with solubilized human thyroid membranes we confirmed again that the IgG had no enhancing effect. Using fat cell membranes we observed only inhibition of binding with $\operatorname{IgG}, \mathrm{F}\left(\mathrm{ab}^{\prime}\right)_{2}$, and Fab (data not shown). In Fig. 4 are shown TBI assays with human thyroid membranes (particulate) and the whole molecule and fragments of DeL's IgG. There was parallel inhibition of binding by all three preparations and the effects were equipotent in molar terms, $F\left(a b^{\prime}\right)_{2}$ being approximately two-thirds and Fab one-third the molecular weight of IgG.

In attempts to separate the activities identified in M's IgG, we performed a series of experiments in which the IgG was ad-

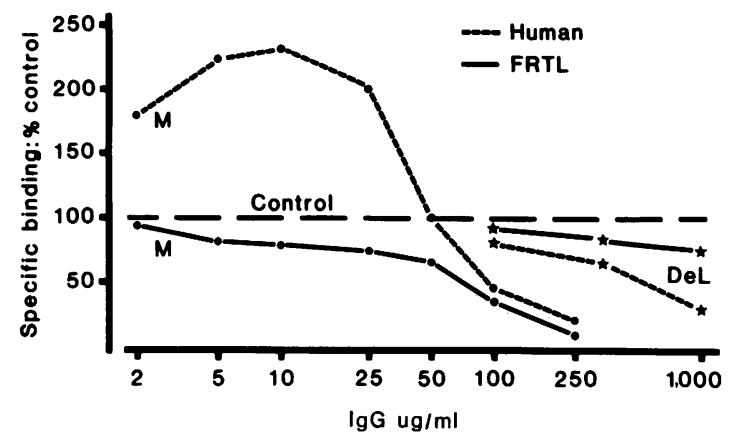

Figure 2. TBI assays using human thyroid and $\mathrm{FRTL}_{5}$ cells in culture. For both assays cells in 24-well plates were used; $10^{6}$ human and $10^{5}$ FRTL 5 cells were incubated with test materials for $1 \mathrm{~h}$ at $37^{\circ} \mathrm{C}$. (For more details see Methods.) $\mathbf{M}=$ response to patient's IgG. $\mathrm{DeL}=$ response to standard TSAb-IgG. Each point is the mean of closely agreeing duplicates in replicate assays. Specific binding with human thyroid cells was low (3.5\%, with nonspecific of $0.4 \%$ ), but the curves obtained in replicate assays with the addition of $\mathrm{IgG}$ were indistinguishable. There was no overlap of the values at any of the points. For FRTLs cells the specific binding was $18.5 \%$ (nonspecific $1 \%$ ). The effects of

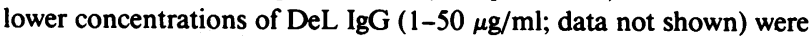
not significantly different from control. 


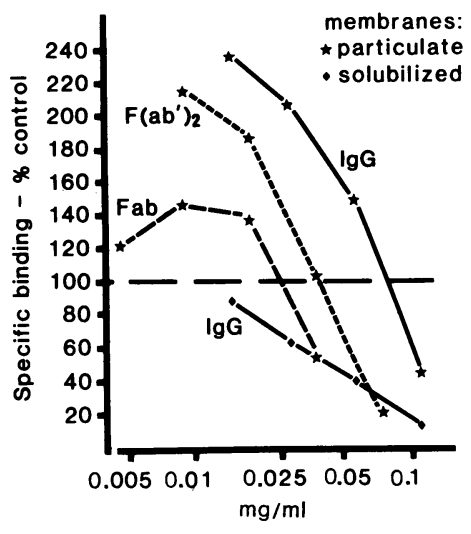

Figure 3. TBI assay with human thyroid membranes, particulate and solubilized. Effects of M's IgG and its fragments are shown. Each point is the mean of closely agreeing triplicate observations in replicate assays. Membranes: particulate $=20 \mu \mathrm{g}$ protein, specific binding $20.8 \%$ (nonspecific $3.2 \%$; solubilized $=15 \mu \mathrm{g}$ protein, specific binding $23.9 \%$ (nonspecific $9.6 \%$ ). Control $=$ specific binding of ${ }^{125}$ I-TSH in the presence of buffer alone. Normal IgG at concentrations used in this experiment had no effect on TSH-binding. Lower concentrations of M's IgG (down to $1 \mu \mathrm{g} / \mathrm{ml}$; data not shown) had no significant effect on the solubilized receptor preparation.

sorbed to human thyroid or fat cell membranes and then desorbed from those preparations. The following solutions were obtained and assayed: original $\mathrm{IgG} \kappa, \operatorname{IgG} \kappa$ not adsorbed by membranes, and IgG $\kappa$ desorbed from membranes (Table I). TBI assays of these preparations, using human thyroid membranes as receptors $\left(\mathrm{TBI}_{\mathrm{ht}}\right)$ are shown in Fig. 5; in Fig. 6 the data obtained with guinea pig fat cell membranes as receptors $\left(\mathrm{TBI}_{\mathrm{gp}}\right)$ are de-

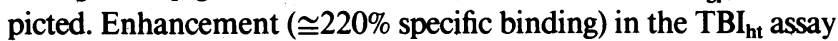
was observed with the original IgG $\kappa$, that desorbed from thyroid, and $\mathrm{IgG} \kappa$ that was unadsorbed by either fat or thyroid; except for the $\mathrm{IgG} \kappa$ that was not adsorbed by thyroid, all these preparations were inhibitory at high concentrations. As shown in Fig. 6 , no preparation enhanced binding of the thyrotropin to fat cell membranes. The most potent inhibitor in either system was the $\mathrm{IgG} \kappa$ desorbed from fat cell membranes and this was devoid of any enhancing effect in the $\mathrm{TBI}_{\mathrm{ht}}$ assay.

$T S A b$ assays. To test the zoological specificity of the biphasic action of M's IgG in the TSAb assay, i.e., stimulatory only at low concentrations (6), FRTL 5 and human thyroid cells were used. An example of the actions of M's IgG on human thyroid cells in culture is shown in Fig. 7;5 $\mu \mathrm{g} / \mathrm{ml}$ was stimulatory, 100 $\mu \mathrm{g} / \mathrm{ml}$ less so, and $1 \mathrm{mg} / \mathrm{ml}$ ineffective. The standard TSAb-lgG stimulated at 10 and $100 \mu \mathrm{g} / \mathrm{ml}$ and these effects were inhibited

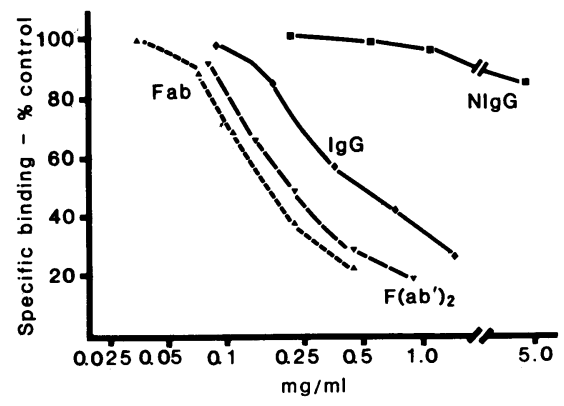

Figure 4. TBI assay with human thyroid membranes (particulate). Effects of DeL's IgG and fragments are shown. NIgG = control pooled normal IgG. Each point is the mean of closely agreeing triplicate observations in replicate assays. The same batch of membranes as in Fig. 6 was used. Control specific binding, i.e., with $0.9 \% \mathrm{NaCl}-0.2 \% \mathrm{BSA}$ (see Methods), was 20.2\%. Lower concentrations of the test preparations (data not shown) had no significant effect on TSH-binding.

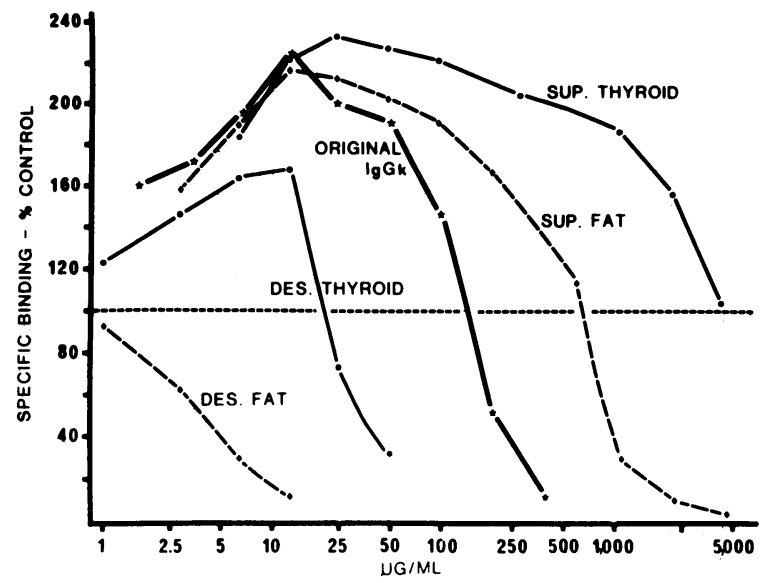

Figure 5. TBI assay with human thyroid membranes (particulate). Effects of various preparations of M's IgG $k$ are shown. Des. Fat and Des. Thyroid = IgG $\kappa$ desorbed from fat and thyroid membranes, respectively. Sup. Fat and Sup. Thyroid $=\mathrm{IgG}_{\kappa}$ not adsorbed to the respective membranes. See Methods for details of preparation. Each point represents the mean of closely agreeing triplicate observations in replicate assays. The same batch of membranes as in Fig. 6 was used. Control $=$ specific binding $(19.6 \%)$ in the presence of $0.9 \% \mathrm{NaCl}-0.2 \%$ BSA (see Methods). Lower concentrations of Des. Fat IgG (data not shown) had no significant effect on TSH-binding.

progressively by increasing concentrations of M's IgG. With $\mathrm{FRTL}_{5}$ cells there was a dose-dependent decrement of basal cAMP concentration with $0.002-0.2 \mathrm{mg}$ M's IgG $/ \mathrm{ml}$ (as percent of cAMP concentration in control wells, $0.002 \mathrm{mg} \mathrm{IgG}=96$; $0.01 \mathrm{mg}=76 ; 0.05 \mathrm{mg}=68 ; 0.2 \mathrm{mg}=58$ ), and not dosedependent, with $0.2-2 \mathrm{mg} \mathrm{M}$ 's IgG per ml (Fig. 8); the cells were fully responsive to $0.4 \mathrm{mg}$ DeL's IgG or $50 \mu \mathrm{U} \mathrm{TSH} / \mathrm{ml}$. Both DeL's IgG and TSH were inhibited by addition of M's IgG.

In a single experiment with simian thyroid slices the tissue was found to respond well to TSH and to DeL's IgG but not at all to $\mathrm{M}$ 's IgG at 0.12 and $0.45 \mathrm{mg} / \mathrm{ml}$ (data not shown). Similarly, porcine thyroid slices (from the glands used for the TBI assays illustrated in Fig. 1) were responsive to DeL's IgG but

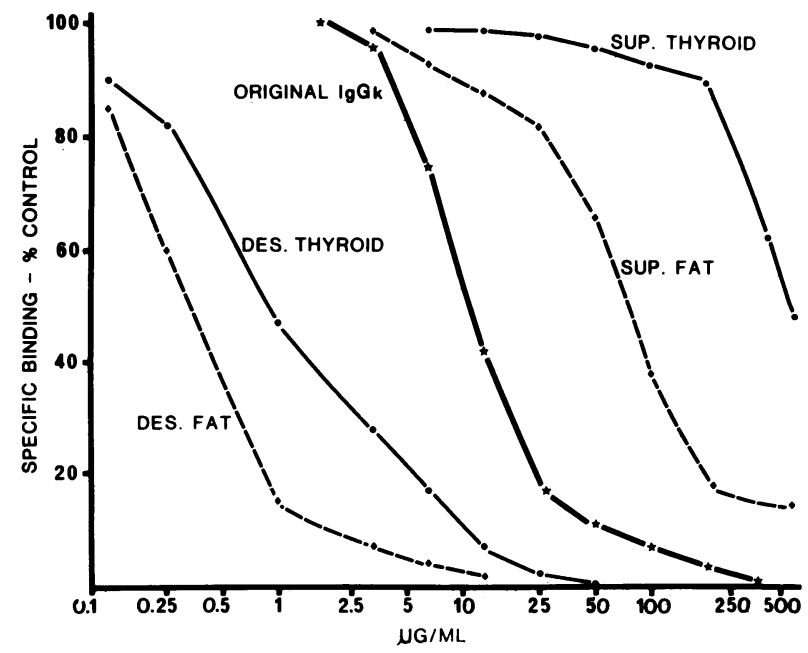

Figure 6. TBI assay with guinea pig fat cell membranes (particulate). Effects of various preparations of M's IgG $x$. See legend to Fig. 5. Membranes: $20 \mu \mathrm{g}$ protein, specific binding $18.5 \%$ (nonspecific $2.6 \%$ ). 


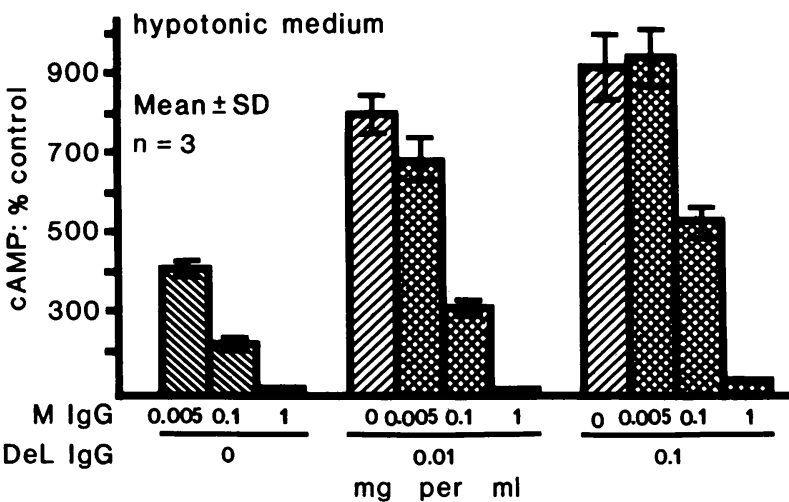

Figure 7. Stimulation of human thyroid cells in culture. As indicated, hypotonic medium was used (see Methods). The effects of combinations of M's IgG and a standard (DeL) TSAb-IgG are shown. Control $=$ medium alone. $2.5 \times 10^{4}$ cells per well in a 96-well plate were used. Incubations with test solutions were for $4 \mathrm{~h}$ at $37^{\circ} \mathrm{C}$, after which cAMP in the medium was measured. The concentration of cAMP in the medium of control wells was $0.65 \mathrm{pmol} / \mathrm{well}$.

not to M's IgG; with tissue from the 2-yr-old pig representative responses (percent increase in cAMP over control) were as follows: $500 \mu \mathrm{U}$ TSH/ml, 478\%; $500 \mu \mathrm{g}$ DeL's IgG/ml, 278\%; M's $\mathrm{IgG}, 25-500 \mu \mathrm{g} / \mathrm{ml}$, no significant effect. Similar data were obtained with the gland from a 2-mo-old pig.

The action of M's and DeL's IgG and IgG fragments in human thyroid slices is shown in Figs. 9 and 10. Over the range displayed, M's IgG and $F\left(a b^{\prime}\right)_{2}$ were stimulatory whereas the Fab fragment had little effect; in other experiments concentrations of the Fab up to $1 \mathrm{mg} / \mathrm{ml}$ similarly had no marked effect in the assay. The parallelism, and approximate equipotency in molar terms, of stimulation by DeL's IgG, F( $\left(\mathrm{ab}^{\prime}\right)_{2}$, and Fab are shown in Fig. 10.

The influence in the human thyroid slice assay of preparations of $\mathrm{IgG} \kappa$ obtained as outlined in Table $\mathrm{I}$ is shown in Fig. 11. The IgG $\kappa$ desorbed from fat had no effect up to $10 \mu \mathrm{g} / \mathrm{ml}$

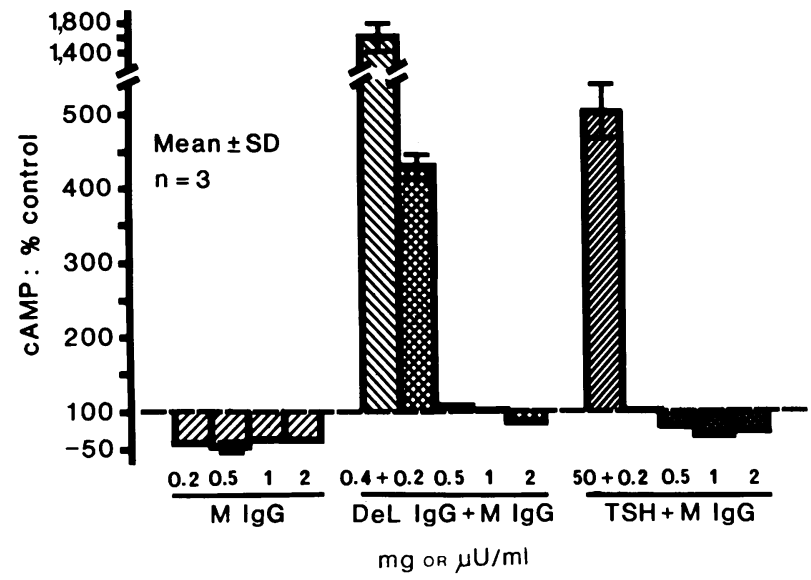

Figure 8. Stimulation of FRTLs cells in culture. The experimental design was as in Fig. 7, except that interactions of TSH and M's IgG were also studied. The abscissa indicates the concentration of IgG (milligrams per milliliter) or TSH (microunits per milliliter) tested singly or in combination; the combinations were as shown, i.e., $0.4 \mathrm{mg}$ $\mathrm{DeL} \mathrm{IgG} / \mathrm{ml}$ or $50 \mu \mathrm{U} \mathrm{TSH} / \mathrm{ml}$, plus the designated concentrations $(0.2-2 \mathrm{mg} / \mathrm{ml})$ of $\mathrm{M} \mathrm{IgG}$. The concentration of cAMP in the cells of control wells was $2.4 \mathrm{pmol} /$ well.

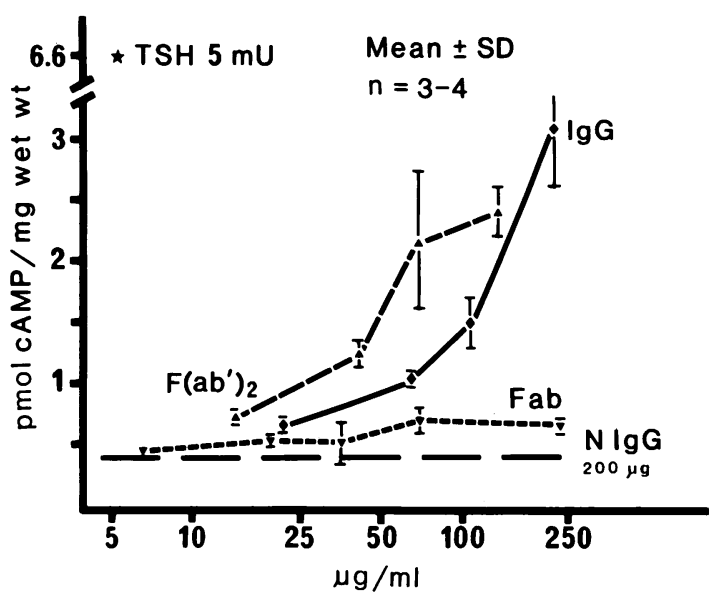

Figure 9. TSAb assay in human thyroid slices. Effects of M's IgG and fragments. $\mathrm{NIgG}=$ control pooled normal IgG at $200 \mu \mathrm{g} / \mathrm{ml}$. Incubation of slices with test preparations was for $2 \mathrm{~h}$ at $37^{\circ} \mathrm{C}$, after which tissue was removed and processed for measurement of cAMP (see Methods for details).

although 2-10 $\mu \mathrm{g} \operatorname{lgG} \kappa$ desorbed from thyroid gave concentration-related stimulation. The IgG $\kappa$ not adsorbed by thyroid was indistinguishable in effect from the original $\mathrm{IgG} \kappa$ but that not adsorbed by fat cell membranes was qualitatively different; at the highest of the three concentrations tested $(125 \mu \mathrm{g} / \mathrm{ml})$ there may have been a plateauing of stimulation, similar to what was observed with the original IgG $\kappa$ in a previous assay (6).

The failure to recover TSAb activity from fat cell membranes was unexpected, so that another preparation of TSAb-IgG (i.e., normal TSAb-lgG, from another Graves' disease subject) was treated similarly. IgG with markedly increased specific activity in the TSAb assay was recovered (data not shown).

To summarize these findings the following may be stated. (a) The enhancing effect of M's IgG on ${ }^{125} \mathrm{I}-\mathrm{TSH}$ binding to membranes was seen only with particulate thyroid membranes, was most marked with human material (and not at all with $\mathrm{FRTL}_{5}$ cells), and required a divalent $\mathrm{F}\left(\mathrm{ab}^{\prime}\right)_{2}$ molecule. It could be recovered from thyroid membranes to which it was bound but not from fat membranes. (b) M's IgG was stimulatory (TSAb assays) only at low concentrations and only in human thyroid preparations; it was nonstimulating at a wide range of concen-

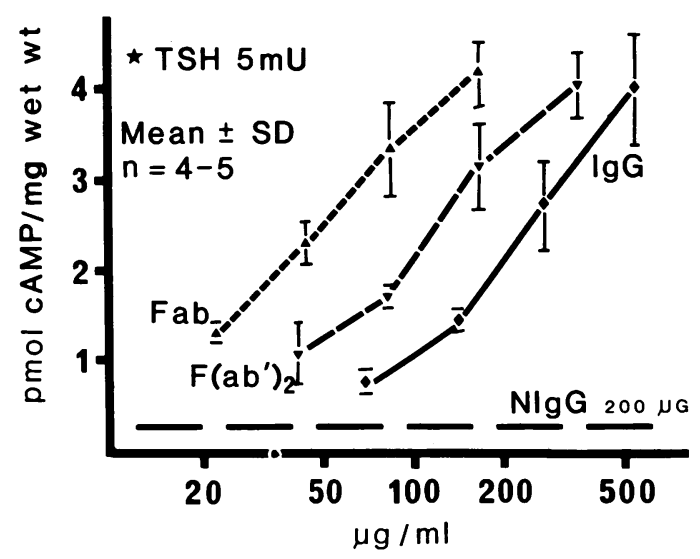

Figure 10. TSAb assay in human thyroid slices. Effects of DeL's IgG and fragments. See legend to Fig. 9. 


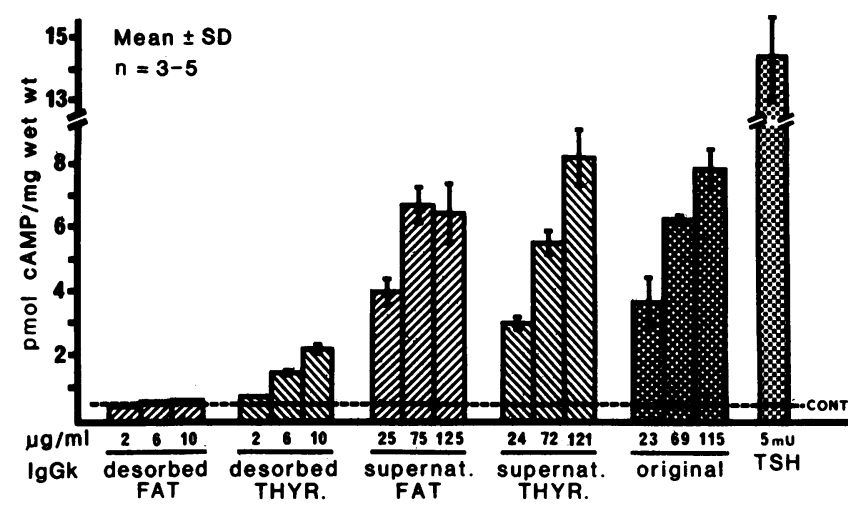

Figure 11. TSAb assay with human thyroid slices. Effects of various preparations for M's IgG $x$. See legend to Fig. 5. Incubation of slices with test preparations was for $2 \mathrm{~h}$ at $37^{\circ} \mathrm{C}$, after which tissue was removed and processed for measurement of cAMP (see Methods for details).

trations in porcine and simian thyroid slices and in FRTL $\mathrm{FL}_{s}$ cells. The IgG inhibited stimulation by another TSAb-IgG and TSH in human thyroid and FRTL 5 cell systems. Unlike normal TSAb, stimulation was not retained by the Fab fragment. TSAb activity could be adsorbed to and recovered from thyroid membranes, but not from fat cell membranes.

\section{Discussion}

The IgG under study came from a woman who had had three children with neonatal Graves' disease, all with a delay of several weeks in the onset of symptoms; the second and third child were clearly identified as having developed hyperthyroidism at around $45 \mathrm{~d}$ of age, as forecast on the basis of studies with the first child. The data indicated that the delay was associated with the maternal IgG containing not only TSAb, but an inhibitor of TSAb action. The evidence supporting this claim included (6) (a) a biphasic dose-response relationship in the TSAb assay of the mother's IgG, i.e., over the range of $20 \mu \mathrm{g}$ to $10 \mathrm{mg} \mathrm{IgG/ml}$ there was a progressive increase in the formation of cAMP and then a decrement back to control concentrations. (b) Another biphasic effect of the IgG was that at low concentrations there was enhancement of binding of ${ }^{125} \mathrm{I}$-TSH to human thyroid membranes $\left(\mathrm{TBI}_{\mathrm{ht}}\right.$ assays), followed by inhibition of binding at higher concentrations of IgG. (c) Testing the IgG in the longacting thyroid stimulator-protector assay (18) showed that an inhibition of that system could be removed with stepwise dilution up to $1: 200$. $(d)$ The mother's IgG inhibited a standard preparation of long-acting thyroid stimulator in the mouse bioassay (6).

We have now identified additional characteristics of this mother's IgG. These may be listed as follows, first from the data obtained with TBI assays. Enhancement of binding of ${ }^{125} \mathrm{I}$-TSH was almost restricted to the system using human thyroid membranes in particulate form or human thyroid cells in culture. That is, minor enhancement occurred with membranes from bovine thyroid, even less with those from an adult pig, and none with preparations from a young pig; rat thyroid cells in culture responded with no enhancement but were very sensitive to the action of inhibition of binding. Solubilization of human thyroid membranes resulted in loss of enhancement of binding, although the preparation was effective as a TSH-receptor with inhibition by M's IgG.

Unlike inhibition of TSH-binding that was effected equally by the $F\left(a b^{\prime}\right)_{2}$ and Fab fragments, from either M's IgG or our standard TSAb-IgG (DeL's), enhancement of binding was minimal with M's IgG Fab, although the $F\left(a b^{\prime}\right)_{2}$ fragment was fully active in this regard. Thus, apparently, while inhibition of TSHbinding reflects a monovalent (i.e., only one antigen-binding site) action of IgG molecule as reported by others (19), enhancement of binding is an action requiring a divalent mechanism and intact, or at least particulate, membranes.

In studies of stimulation of thyroids from different species by the various preparations of M's IgG, additional characteristics emerged. As TSAb, M's IgG was effective only in human tissue or cells, and not with glands from baboon, pig, or rat (the last as FRTLs cells). We previously showed that this IgG does not stimulate the mouse thyroid in vivo (6) although, in general, TSAb that is highly potent in the human thyroid stimulates that of mouse and several other mammalian species in vitro (20). Furthermore, unlike findings with a standard TSAb-IgG (DeL's), stimulation of the human thyroid with M's IgG apparently required the divalent molecular structure, i.e., $\operatorname{IgG}$ or $\mathrm{F}\left(\mathrm{ab}^{\prime}\right)_{2}$, since the Fab fragment was almost totally inactive.

The activity of Fab (monovalent) fragment of TSAb-IgG is unlike what has been described for another bioactive autoantibody, namely, that against the receptor for insulin (21). However, our findings are similar to those reported by others $(19,22)$. Consequently, the concept for the activity of the antibody to the insulin receptor, i.e., that cross-linking of receptor molecules by divalent antibody preparations is essential (21), apparently does not apply to TSAb or TBI activity of IgG but may be relevant for the enhancement of TSH-binding observed with M's IgG.

Adsorption of TSAb-IgG to thyroid membranes, with concentration of the activity on recovery by desorption with acid, is a procedure we described previously, using either bovine or human thyroids (23); similar recovery and concentration of bioactivity with the use of fat cell membranes was described by others (24) and is now confirmed by us. Using these procedures M's IgG yielded preparations that varied qualitatively as well as quantitatively. The nonadsorbed supernatant solution from thyroid membranes contained TSAb, the TSH-binding enhancer and little inhibitor of TSH-binding; that desorbed from the thyroid membranes was qualitatively similar to the original IgGk although having lost some TSH-binding enhancing potency. It was more inhibitory in the TBI assays than the parent molecule, but there was no increase in specific activity in the TSAb assay. The most impressive qualitative change was in the IgG $\kappa$ desorbed from fat; this material contained only inhibitor of TSH-binding and neither thyroid-stimulating nor binding-enhancing activities.

With the membranes to IgG ratios used, we exceeded the capacity of the membranes for different antibodies occurring in M's IgG. Nonetheless, the data indicate that the IgG contains at least three activities that may be identified as follows. (a) TSAb: there is no doubt that stimulation of the human thyroid occurred in vitro and in vivo. (b) An inhibitor of TSH-binding: it was active in all species and preparations tested and was effective in monovalent, $\mathrm{Fab}$, and divalent, $\mathrm{F}\left(\mathrm{ab}^{\prime}\right)_{2}$, forms, and on solubilized thyroid membranes. $(c)$ An enhancer of TSH-binding: it was specific for thyroid membranes and most effective on the human gland, having minor effects on membranes from only the calf and adult pig. It should be noted that the enhancing activity was 
apparently now adsorbed by fat so that the IgG $\kappa$ desorbed from those membranes presumably contained primarily inhibitor of TSH-binding and some TSAb. The IgG $\kappa$ desorbed from fat did not stimulate the human thyroid and it may be that in M's IgG TSAb activity is cependent on an enhancing action of the putative third antibody.

If these speculations are correct it is reasonable to assume that the three antibodies are present in differing concentrations, with disparate affinities for their respective antigens that in turn have different capacities for the antibodies. Thus, the effect on either thyroid stimulation or TSH-binding will depend upon dilution, effected directly in vitro and by metabolic clearance in vivo in the neonates. For instance, at birth, due to a greater capacity of thyroid antigen for the inhibitor of TSH and TSAb, the effect of the inhibitor might be paramount; then, as dilution occurs, TSAb would become overt, in line with the in vitro data. Perhaps TSAb activity depends on the enhancing action of the third antibody, which might have a high affinity for its respective antigen, which apparently was in low concentration. The concept of a low capacity of the antigen for the enhancing antibody is supported by the data showing that the enhancing activity was low in the preparation desorbed from the thyroid membranes, with no increase in the specific activity of TSAb, and much higher in the nonadsorbed supernatant. The activity of TSAb, which is probably present in a very small amount, would depend on the ratio of the enhancing to inhibiting antibody, although the concentration of TSAb would determine the maximum response to be obtained. No stimulatory action of the whole IgG on nonhuman thyroids, therefore, may speak for the importance of the human specific enhancing IgG and of the inhibitory effect of the second antibody.

\section{Acknowledgment}

Support for this work was provided by U. S. Public Health Service grant No. AM 31391.

\section{References}

1. Zakarija, M., J. M. McKenzie, and K. Banovac. 1980. Clinical significance of assay of the thyroid-stimulating antibody of Graves' disease. Ann. Intern. Med. 93:28-32.

2. Zakarija, M., and J. M. McKenzie. 1983. Pregnancy-associated changes in the thyroid-stimulating antibody of Graves' disease and the relationship to neonatal hyperthyroidism. J. Clin. Endocrinol. Metab. 57:1036-1040.

3. Zakarija, M., and J. M. McKenzie. 1983. Thyroid-stimulating antibody (TSAb) of Graves' disease. Life Sci. 32:31-44.

4. Smith, B. R., and R. Hall. 1974. Thyroid-stimulating immunoglobulins in Graves' disease. Lancet. ii:427-431.

5. Kishihara, M., Y. Nakao, Y. Baba, S. Matsukura, K. Kuma, and T. Fujita. 1979. Interaction between thyroid-stimulating immunoglobulins and thyrotropin receptors in fat cell membranes. J. Clin. Endocrinol. Metab. 49:706-711.
6. Zakarija, M., J. M. McKenzie, and D. S. Munro. 1983. Immunoglobulin $\mathrm{G}$ inhibitor of thyroid-stimulating antibody is a cause of delay in the onset of neonatal Graves' disease. J. Clin. Invest. 72:1352-1356.

7. Koizumi, Y., M. Zakarija, and J. M. McKenzie. 1982. Solubilization, purification and partial characterization of thyrotropin receptor from bovine and human thyroid glands. Endocrinology. 110:1381-1391.

8. Ambesi-Impiombato, F., L. A. M. Parks, and H. G. Coons. 1980. Culture of hormone dependent epithelial cells from rat thyroids. Proc. Natl. Acad. Sci. USA. 77:3455-3459.

9. Vitti, P., C. M. Rotella, W. A. Valente, J. Cohen, S. M. Aloj, P. Laccetti, F. S. Ambesi-Impiombato, E. F. Grollman, A. Pinchera, R. Toccafondi, and L. D. Kohn. 1983. Characterization of the optimal stimulatory effects of Graves' monoclonal and serum immunoglobulin $\mathrm{G}$ on adenosine $3^{\prime}, 5^{\prime}$-monophosphate production in $\mathrm{FRTL}_{5}$ thyroid cells: a potential clinical assay. J. Clin. Endocrinol. Metab. 57:782-791.

10. Rapoport, B., F. S. Greenspan, S. Filleti, and M. Pepitone. 1984. Clinical experience with a human thyroid cell bioassay for thyroid-stimulating immunoglobulin. J. Clin. Endocrinol. Metab. 58:332-338.

11. Rapoport, B., S. Filetti, N. Takai, P. Seto, and G. Halverson. 1982. Studies on the cyclic AMP response to thyroid stimulating immunoglobulins (TSI) and thyrotropin (TSH) in human thyroid cell monolayers. Metab. Clin. Exp. 31:1159-1167.

12. Zakarija, M. 1983. Immunochemical characterization of the thyroid-stimulating antibody (TSAb) of Graves' disease: evidence for restricted heterogeneity. J. Clin. Lab. Immunol. 10:77-85.

13. Stanworth, D. R., and M. W. Turner. 1978. Immunochemical analysis of immunoglobulins and their sub-units. In Handbook of Experimental Immunology. D. M. Weir, editor. Blackwell Scientific Publications, Oxford. Third ed. 6.1-6.21.

14. Franklin, E. C. 1960. Structural units of human $7 \mathrm{~S}$ gamma globulins. J. Clin. Invest. 39:1933-1941.

15. Lowry, O. H., N. J. Rosebrough, A. L. Farr, and R. J. Randall. 1951. Protein measurement with the Folin phenol reagent. J. Biol. Chem. 193:265-275.

16. Bradford, M. 1976. A rapid and sensitive method for the quantitation of microgram quantities of protein utilizing the principle of protein-dye binding. Anal. Biochem. 72:248-254.

17. McKenzie, J. M., and M. Zakarija. 1985. Assays of thyroid-stimulating antibody. Methods Enzymol. 109:677-691.

18. Kendall-Taylor, P., S. Dirmikis, and D. S. Munro. 1974. The detection and significance of LATS-protector. $Q$. J. Med. 43:619-620.

19. Smith, B. R. 1976. Immunology of the thyrotropin receptor. Immunol. Commun. 5:345-360.

20. Zakarija, M., and J. M. McKenzie. 1978. Zoological specificity of human thyroid-stimulating antibody. J. Clin. Endocrinol. Metab. 47: 249-254.

21. Kahn, C. R., K. L. Baird, D. B. Jarrett, and J. S. Flier. 1978. Direct demonstration that receptor crosslinking or aggregation is important in insulin action. Proc. Natl. Acad. Sci. USA. 75:4209-4213.

22. Parkes, A. B., F. M. Creagh, F. Hashim, and B. R. Smith. 1985. Thyroid stimulation by monovalent and divalent fragments of Graves' IgG. J. Endocrinol. 104(Suppl):80a. (Abstr.)

23. Zakarija, M., and J. M. McKenzie. 1978. Adsorption of thyroidstimulating antibody (TSAb) of Graves' disease by homologous and heterologous thyroid tissue. J. Clin. Endocrinol. Metab. 47:906-908.

24. Endo, K., S. M. Amir, and S. H. Ingbar. 1981. Development and evaluation of a method for the partial purification of immunoglobulins specific for Graves' disease. J. Clin. Endocrinol. Metab. 52:1113-1123. 